20

I N S A N

\title{
Hubungan Cyberloafing dengan Innovative Work Behavior pada Pekerja Generasi Milenial dalam Industri Kreatif Digital
}

\author{
KURNIA SRI WIJANARKO \& HERISON PANDAPOTAN PURBA* \\ Departemen Psikologi Industri dan Organisasi, Fakultas Psikologi Universitas Airlangga
}

\begin{abstract}
ABSTRAK
Sejauh mana perusahaan dapat berinovasi ditentukan oleh perilaku kerja inovatif dari masing-masing pekerja, terutama pekerja generasi milenial yang mendominasi di era digital sekarang yang mengaburkan batasan kerja dengan kehidupan pribadi. Hal ini memunculkan fenomena cyberloafing. Penelitian ini menggunakan pendekatan kuantitatif dengan teknik survei secara online. Teknik sampling yang digunakan adalah non-probability sampling bertipe purposive sampling. Jumlah subjek penelitian sebanyak 103 responden yang tersebar di berbagai industri kreatif digital di Indonesia. Alat pengumpulan data berupa kuesioner cyberloafing dan alat ukur Innovative Work Behaviour. Analisis data dilakukan dengan teknik statistik korelasi Bivariate Pearson dengan bantuan program IBM SPSS Statistic 25 for Windows. Hasil penelitian menunjukkan bahwa terdapat hubungan yang kuat dengan arah hubungan positif $(r(103)=0,518, p<0,05)$ antara cyberloafing dengan innovative work behaviour generasi milenial yang bekerja di industri kreatif digital.
\end{abstract}

Kata kunci: cyberloafing, IWB, kreatif digital, milenial

\begin{abstract}
The extent to which companies can innovate is determined by the innovative work behavior of each worker, especially millennial generation workers who dominate in the current digital era that blur the boundaries of work with personal life. This gave rise to the phenomenon of cyberloafing. This research used a quantitative approach with online survey techniques. The sampling technique used is nonprobability sampling with the type of purposive sampling. The number of research subjects is 103 respondents spread across various digital creative industries in Indonesia. Data collection tools such as cyberloafing questionnaires and innovative work behavior measurement tools. Data analysis was performed using Bivariate Pearson statistical correlation techniques with the help of the IBM SPSS Statistics 25 for Windows. The results showed that there was a strong relationship with the direction of a positive relationship $(r(103)=0.518, \mathrm{p}<0.05)$ between cyberloafing and millennial generation innovative work behavior working in the digital creative industry.
\end{abstract}

Keywords: cyberloafing, digital creative, IWB, millennial 
INSAN Jurnal Psikologi dan Kesehatan Mental, 2018, Vol. 3(2), 101-113, doi: 10.20473/jpkm.v5i22018.101-113 Dikirimkan: 16 Oktober 2019 Diterima: 10 Desember 2019 Diterbitkan: 26 Februari 2020

Editor: Dewi Syarifah

*Alamat korespondensi: Fakultas Psikologi Universitas Airlangga, Jalan Airlangga 4-6 Surabaya 60286. Pos-el: herison.purba@psikologi.unair.ac.id

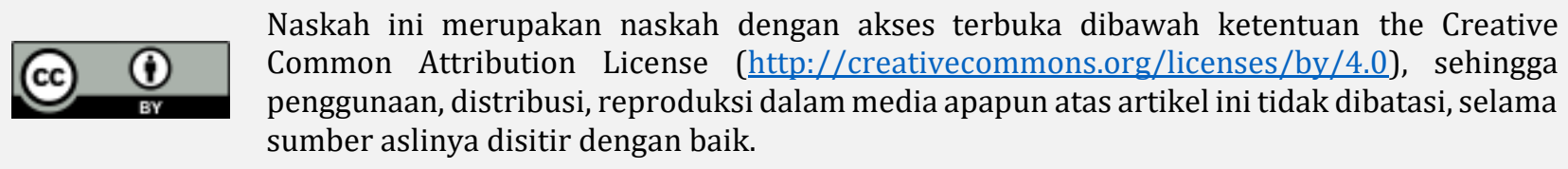

\section{P E N D A H U L U A N}

Inovasi merupakan salah satu kekuatan pendorong yang paling penting dari pengembangan, perubahan, dan diferensiasi. Inovasi juga dapat diterima sebagai indikator yang mendasar untuk kompatibilitas organisasi dan negara (Derin \& Gökçe, 2016). Namun, kapabilitas inovasi Indonesia dalam The Global Talent Competitiveness Index (GTCI) menjadi komponen dengan peringkat terendah dibandingkan komponen lainnya, di sisi lain, input-output inovasi dalam Global Innovation Index (GII) juga masih tergolong rendah dibandingkan negara tetangga (Cornell University dkk., 2018).

Sumber daya manusia adalah dasar untuk inovasi dan evaluasi karyawan, sekaligus sebagai strategi untuk mengatasi persaingan global dan ketidakpastian, guna mencapai tingkat kinerja yang tinggi dan tujuan organisasi (Derin \& Gökçe, 2016). Maka dari itu, diperlukannya peningkatan perilaku kerja inovatif (innovative work behavior) dari sumber daya manusia guna mengembangkan kemampuan inovasi organisasi itu sendiri. Sesuai dengan penelitian yang dilakukan oleh Aslam, Aslam, \& Ismail (2017) yang menyatakan bahwa terdapat efek positif yang signifikan dari innovative work behaviour terhadap innovative output. Beberapa penelitian terdahulu juga berpendapat bahwa sejauh mana perusahaan dapat terus berinovasi berkaitan dengan inovasi oleh karyawan secara individual (Aslam dkk., 2017).

IWB dapat dipengaruhi faktor internal individu selaku sumber daya manusia dan faktor kontekstual diluar individu. Faktor kontekstual yang menarik untuk penulis teliti adalah pengaruh dari adanya transisi revolusi industri 3.0 pada abad ke-20 ke revolusi industri 4.0 pada abad ke-21 saat ini yang berdampak pada semakin kuatnya pemanfaatan teknologi digital dan internet (Derin \& Gökçe, 2016). Sehingga saat ini hampir mustahil untuk bekerja tanpa adanya koneksi internet (Derin \& Gökçe, 2016). Chatzoglou \& Vraimaki (2010) menyatakan bahwa penggunaan internet dianggap sebagai perilaku inovatif itu sendiri.

Karena itu, perusahaan yang mengusung atau menerapkan ekonomi digital yang menggabungkan berbagai teknologi akses internet dalam kegiatan perekonomian semakin bermunculan, terutama di negara berkembang (Bukht \& Heeks, 2017), termasuk Indonesia. Oleh karena itu, organisasi serta perusahaan bintang/ startup digital dewasa ini yang memiliki aliansi longgar sedang mencari cara untuk mendorong inovasi yang lebih besar (Theurer dkk., 2018) Proses digitalisasi ekonomi ini sudah memiliki dampak yang cukup besar pada industri kreatif. Digitalisasi mengubah cara karya kreatif dihasilkan, disebarluaskan, dan digunakan. Digitalisasi juga memungkinkan pengembangan jenis barang dan jasa kreatif baru, seperti video game, dan cara-cara baru untuk membiayai kreativitas, seperti pendanaan kerumunan, dan hal itu mengaburkan batas antara produsen dan konsumen (Handke \& Towse, 2016). 
Di sisi lain, abad ke-21 ini, setiap hari masyarakat modern selalu menggunakan teknologi untuk menunjang aktivitas, terutama teknologi informasi dan komunikasi, yaitu internet (Internet World Stats, 2017). Sekarang ini hampir semua individu memiliki komputer atau smartphone pribadi yang mereka gunakan di dalam dan di luar jam kerja. Akibatnya dalam dua dekade terakhir, batas-batas antara pekerjaan dan kehidupan non-kerja menjadi semakin kabur dengan adanya internet (Allen dkk., 2017). Kemudian muncul fenomena Cyberloafing yang merupakan penggunaan internet di saat jam kerja untuk kepentingan pribadi.

Cyberloafing dianggap sebagai bentuk penyimpangan produksi di tempat kerja (Lim, 2002; Lim \& Teo, 2005), hal ini karena kegiatan dunia maya yang dilakukan di tempat kerja selama waktu kerja merupakan penggunaan waktu yang tidak produktif dan dianggap mengurangi intensi karyawan dalam menyelesaikan tuntutan pekerjaan mereka. Sehingga cyberloafing dapat dianggap sebagai jenis perilaku kerja kontraproduktif (CWB), yaitu perilaku yang membahayakan organisasi dan/atau pemangku kepentingan organisasi (Spector dkk., 2005).

Cyberloafing memecahkan fokus kognitif membutuhkan waktu dan energi untuk fokus kembali pada tugas asli, karena gangguan ini terjadi, ada peningkatan peluang kesalahan kerja (Ross, 2018). Cyberloafing menyebabkan berkurangnya keterlibatan di tempat kerja karena karyawan tidak berinteraksi dan membangun hubungan yang bermakna dengan kolega lain selama waktu luang mereka (Koay \& Soh, 2018). Cyberloafing juga dianggap dapat menurunkan kinerja dan produktivitas perusahaan dan bertentangan dengan etnik kerja yang membahayakan bagi organisasi (Lim \& Chen, 2012; Olajide dkk., 2018)

Namun, cyberloafing tidak selalu buruk, bahkan cyberloafing dapat membantu karyawan untuk mengurangi stres dan kelelahan kerja. Karyawan adalah sumber daya manusia yang membutuhkan waktu untuk mengisi kembali energi mereka. Ketika karyawan bahagia dan berenergi, mereka mungkin bekerja keras di tempat kerja mereka, yang mengarah pada kinerja yang lebih baik. Namun, karyawan tidak boleh menghabiskan terlalu banyak waktu untuk cyberloafing, karena dapat melebihi manfaatnya. Selain itu, karyawan dapat memperoleh perspektif atau ide baru dan segar dari istirahat (cyberloafing), kemudian menginvestasikan kembali dan menerjemahkan pembelajaran tersebut ke dalam tugas yang terkait dengan pekerjaan (Koay \& Soh, 2018).

Berdasarkan beberapa penelitian terdahulu lainnya, menemukan hasil bahwa terdapat hubungan yang positif antara cyberloafing dengan innovative work behaviour (Derin \& Gökçe, 2016; Yogun, 2015). Derin \& Gökçe (2016) menggunakan variabel IWB dan cyberloafing unidimensional menunjukkan bahwa adanya hubungan positif yang lemah antara cyberloafing dan IWB. Doorn (2011) menyatakan bahwa cyberloafing bisa sangat terkait dengan IWB karena self-development and searching yang merupakan bagian dari IWB. Yogun (2015) menunjukkan bahwa terdapat dua dimensi yang memiliki korelasi terhadap IWB, yaitu pada dimensi informational activity sebesar $\mathrm{r}=60$ dan dimensi social activity sebesar $r=50$.

Ketika pekerja membaca informasi, secara positif dapat memengaruhi semangat pekerja dalam bekerja (Yogun, 2015). Belanger dan Van Slyke (2002) (dalam Yogun, 2015) menyatakan bahwa cyberloafing dapat mendorong peningkatan pemahaman tentang informasi yang ada. Di sisi lain, interaksi dapat meningkatkan hubungan emosional dan kepercayaan antara anggota, yang tidak hanya kondusif bagi karyawan untuk berbagi pengalaman belajar dan pengetahuan teknologi, tetapi juga memperluas bidang visi, mempromosikan ide-ide baru, dan menghasilkan ide-ide baru. Selain itu, hubungan interpersonal atau sosial yang baik akan menyebabkan perasaan karyawan lebih aman untuk menyuarakan dan berbagi ide-ide secara terbuka (Zhou \& Velamuri, 2018). 
Sementara itu, hasil yang berbeda didapatkan oleh penelitian yang dilakukan oleh Palladan (2018) yang menggunakan cyberloafing sebagai variabel moderator untuk hubungan antara IWB dan Job Performance pada bidang kerja pendidik atau dosen, menemukan bahwa adanya efek moderasi yang negatif dari aktivitas cyberloafing pada IWB dan Job Performance dosen di Nigeria. Penjelasan ini menunjukkan bahwa cyberloafing dalam kegiatan kuliah dapat menurunkan kemampuan inovasi dosen dan kinerja mereka. Okechukwu (2015 dalam Palladan, 2018) menemukan bahwa dosen di perguruan tinggi Nigeria menggunakan internet di tempat kerja mereka hanya untuk berbincang-bincang di media sosial dan jarang menggunakannya untuk tujuan akademik. Ebele (2014 dalam Palladan, 2018) lebih lanjut menyatakan bahwa tingkat e-learning masih pada tahap pasang surut, yang lebih rendah di antara lembaga-lembaga tersier Nigeria lainnya, hal ini disebabkan oleh buruknya adopsi TIK oleh dosen.

Keterbatasan pada penelitian-penelitian sebelumnya adalah pada penelitian yang dilakukan dalam sektor bank tidak melakukan perbandingan antar sektor dalam bank, karena pengaturan kerja berbagai sektor mungkin agak berbeda dari pengaturan bank karena kebijakan kerjanya (Yogun, 2015). Selain itu, Malachowski (2005 dalam Yogun, 2015) menunjukkan bahwa sektor pendidikan, asuransi, sektor publik, penelitian, dan pengembangan lebih banyak untuk melakukan pemborosan waktu, di mana shipping and receiving, manufacturing, healthcare, finance dan banking, pemasaran, dan sektor komunikasi lebih menghemat waktu. Selain itu, ketika tidak memberi fokus pada bidang kerja yang membutuhkan kreatifitas dan inovasi dinilai menyebabkan hubungan antara cyberloafing dengan innovative work behaviour lemah (Derin \& Gökçe, 2016). Di sisi lain, tidak semua bidang pekerjaan membutuhkan inovasi dan hanya mengerjakan sesuai peran yang diperintahkan.

Berdasarkan beberapa hasil kesimpulan dan pertimbangan dari berbagai penelitian sebelumnya, penulis melakukan penelitian terkait hubungan cyberloafing dengan IWB pada industri kreatif digital, karena berfokus pada penciptaan barang dan jasa yang mengandalkan keahlian, kreativitas, ketrampilan, serta bakat individu, dengan memanfaatkan perangkat, aplikasi, dan fungsi teknologi digital internet (Dahlman dkk., 2016; Daniel dkk., 2017; Dinperindag Provinsi Jawa Tengah, 2014; Handke \& Towse, 2016; Levickaitè, 2011).

Selain itu, berdasarkan penelitian sebelumnya terkait hubungan antara cyberloafing dengan IWB tidak menggunakan kriteria berdasarkan generasi subjek penelitian, yang mana menurut Conner (2013) (dalam Kim, 2018) menyatakan bahwa generasi milenial dua kali lipat lebih banyak membuang-buang waktu dari pada generasi baby boomer di tempat kerja. Internet telah memupuk kemampuan milenial untuk berkomunikasi dengan orang lain. Generasi Milelial memandang penggunaan teknologi yang tepat berbeda dari generasi yang lebih tua (Sheaffer, 2009 dalam Kim, 2018).

Lahir dan tumbuh dengan internet dan akses yang tak tertandingi ke teknologi, generasi milenial secara luas menggunakan berbagai teknologi untuk alasan pribadi saat bekerja (Kim, 2018). Namun, penggunaan teknologi milenial secara pribadi di tempat kerja tidak hanya loafing atau bermalasmalasan, tetapi karena didorong oleh nilai kerja mereka yang berbeda, gaya belajar, dan kemampuan melakukan banyak tugas (multitasking proficiency) (Kim, 2018). Selain itu, menurut Budiati dkk., (2018), Indonesia akan menghadapi bonus demografi dengan persentase generasi milenial tahun 2017 sebesar 33,75 persen dari jumlah penduduk keseluruhan dan 50,36 persen dari jumlah penduduk usia produktif, dan akan terus bertambah hingga mendominasi kerja.

\section{MET ODE}

\section{Partisipan}

Populasi yang dipilih dalam penelitian ini adalah pekerja generasi milenial dalam industri kreatif digital di Indonesia yang belum diketahui secara jelas berapa jumlah populasinya. Teknik sampling yang INSAN Jurnal Psikologi dan Kesehatan Mental Tahun 2018, Vol. 3(2), 101-113 doi: $10.20473 /$ jpkm.v5i22018.101-113 
digunakan dalam penelitian ini adalah non-probability sampling, dengan tipe purposive sampling. Jumlah subjek yang berhasil terkumpul adalah sebanyak 103 responden yang tersebar di berbagai industri kreatif digital di Indonesia.

Prosedur

Penelitian ini menggunakan teknik survei yang disebarkan secara online.

\section{Pengukuran}

Instrumen cyberloafing yang digunakan dalam penelitian ini adalah dari Doorn (2011), yang mengembangkan skala cyberloafing berdasarkan berbagai teori dan skala yang telah ada sebelumnya. Doorn membagi cyberloafing menjadi 2 kategori yang berbeda namun saling terkait, yaitu cyberloafing activities dan cyberloafing behavior. Kedua kategori tersebut masing-masing memiliki empat dimensi, yang mana seluruh dimensinya digabung ke dalam satu instrumen skala. Masing-masing dimensi memiliki tiga aitem, sehingga terdapat 24 aitem dalam satu instrumen skala cyberloafing. Penormaan kuesioner ini menggunakan skala likert poin 5, dari skala 1 yang merupakan respon "tidak pernah" dan skala 5 untuk respon "selalu". Skala cyberloafing ini memiliki reliabilitas sebesar 0.840 dan berubah menjadi sebesar 0,803 setelah dilakukan uji ulang oleh penulis menggunakan perangkat lunak SPSS 25 for Windows.

Validitas alat ukur diestimasi dengan menggunakan menggunakan content validity dengan menggunakan empat expert judgement. Instrumen Innovative Work Behaviour (IWB) yang digunakan dalam penelitian ini adalah dari De Jong \& Den Hartog (2010), yang mengembangkan alat ukur Innovative Work Behaviour berdasarkan berbagai alat ukur yang telah ada, terutama mengacu pada alat ukur IWB yang dikembangkan oleh Kanter (1988) dan Janssen (2000), yang mana terdapat satu dimensi yang dipecah menjadi dua, yaitu dimensi idea generation. Idea generation dianggap terlalu luas karena mencakup dua perilaku, yaitu perilaku untuk mengeksplorasi ide dan memunculkan ide yang mana masing-masing perilaku bisa menjadi dimensi tersendiri (De Jong \& Den Hartog, 2010). Selain itu, menurut Shane (2003 dalam De Jong \& Den Hartog, 2010) menyebutkan bahwa mengeksplorasi peluang mendahului adanya pemunculan ide.

Terdapat empat dimensi pada alat ukur IWB yang dikembangkan oleh (De Jong \& Den Hartog, 2010), masing-masing dimensi memiliki jumlah aitem yang berbeda-beda, dengan jumlah seluruh aitem adalah sepuluh aitem. Seperti skala cyberloafing, penormaan kuesioner ini menggunakan skala likert poin 5, dari skala 1 "tidak pernah" dan skala 5 "sangat sering". Selain itu, alat ukur ini diukur oleh supervisor terhadap karyawan. Tetapi aitem yang digunakan bersifat universal, artinya bisa juga diukur oleh diri karyawan sendiri atau self-ratings. Skala IWB ini memiliki reliabilitas sebesar 0.920 dan berubah menjadi sebesar 0,902 setelah dilakukan uji ulang oleh penulis menggunakan perangkat lunak SPSS 25 for Windows. Validitas menggunakan content validity dengan menggunakan empat expert judgement.

\section{Analisis Data}

Penelitian ini menggunakan pendekatan Kuantitatif, dengan jenis explanatory research yang dibangun di atas penelitian eksploratif dan deskriptif, bertujuan untuk mengidentifikasi alasan sesuatu terjadi, memberikan gambaran tentang masalah, mencari penjelasan atas adanya hubungan dan pengaruh dari sebab dan akibat. Teknik pengumpulan data yang digunakan menggunakan teknik survei dengan menggunakan kuesioner secara online. Analisis data dilakukan menggunakan software IBM SPSS Statistics 25 for windows guna mendapatkan hasil uji hipotesis yang berguna untuk menarik kesimpulan. Sebelumnya, dilakukan uji asumsi terlebih dahulu, yang terdiri dari uji normalitas, uji linearitas. Setelah INSAN Jurnal Psikologi dan Kesehatan Mental Tahun 2018, Vol. 3(2), 101-113 doi: 10.20473/jpkm.v5i22018.101-113 
dilakukan uji asumsi, kemudian dilakukan uji atau analisis bivariate pearson untuk mengetahui arah hubungan dan kekuatan hubungan. Kemudian penulis melakukan analisis tambahan untuk mendukung hasil analisis uji hipotesis, yaitu analisis korelasi parsial masing-masing dimensi cyberloafing dengan IWB dan analisis One-Way ANOVA berdasarkan demografis subjek.

\section{H A S I L P E N ELIT IAN}

Berdasarkan hasil pengkategorian skor responden, diketahui bahwa sebagian responden memiliki tingkat cyberloafing dengan kategori sedang, yaitu sebanyak 33 atau 32\% orang. Kemudian sebanyak 30 atau 29,1\% responden memiliki tingkat cyberloafing yang tinggi, di sisi lain terdapat 26 atau 25,2\% responden memiliki tingkat cyberloafing yang rendah. Ada sebanyak 9 atau 8,7\% responden memiliki tingat cyberloafing yang sangat rendah sedangkan pada kategori sangat tinggi terdapat sejumlah 5 atau $4,9 \%$ responden.

Sebagian besar responden yaitu sebanyak 40 atau 38,8\% responden memiliki tingkat IWB yang sedang. Kemudian pada kategori tinggi terdapat 28 atau 27,2\% responden, sebaliknya pada kategori rendah terdapat 19 atau 18,4\% responden. Disisi lain pada kategori sangat rendah terdapat 10 atau 9,7\% responden dan sebaliknya, pada kategori sangat tinggi, terdapat 6 atau 5,8\% responden.

Pada uji normalitas seluruh data penelitian pada setiap variabel dan pada nilai residual terstandarisasi berdistribusi normal, variabel cyberloafing memiliki nilai $(p=0,200)$ dan variabel IWB memiliki nilai $(p=0,174)$. Pada deviation from linearity diketahui bahwa hubungan antar variabel dalam penelitian ini adalah segaris atau linear dengan nilai $(p=0,594)$ selain itu jika dilihat dari hasil skor linearity, terlihat bahwa nilai $(p=0,000)$ yang mana kurang dari 0,05 .

Seluruh uji asumsi dapat terpenuhi, sehingga analisis data untuk menguji hipotesis menggunakan Model Analisis Parametrik dengan menggunakan analisis Korelasi Bivariate Pearson. Didapatkan hasil bahwa terdapat hubungan yang kuat antar kedua variabel dalam penelitian $(r(103)=0,518, p(1$-tailed $)=0,000)$ dengan arah hubungan yang positif.

Pada analisis tambahan, yaitu analisis Korelasi Parsial mendapatkan hasil bahwa dimensi social activity $(r=0,412)$, informational activity $(r=0,483)$, virtual emotional activity $(r=0,322)$, recovery behaviour $(r=0,266)$, development behaviour $(r=0,523)$, dan addiction behaviour $(r=0,398)$ memiliki korelasi dengan IWB dengan beragam besarnya korelasi. Sedangkan pada dimensi leisure activity dan deviant behaviour tidak memiliki korelasi terhadap IWB. Penulis juga melakukan analisis tambahan terkait perbandingan hasil variabel dependent dan independent yang diteliti berdasarkan kelompok variabel demografis, yaitu jenis kelamin, pendidikan terakhir, dan waktu kerja. Pada analisis tambahan perbandingan ini, penulis menggunakan teknik analisis One-Way ANOVA. Analisis ini bertujuan untuk membandingkan nilai ratarata antar kelompok yang dibandingkan terhadap variabel yang dipengaruhi.

Berdasarkan kategori jenis kelamin subjek, hasilnya menunjukkan bahwa subjek berjenis kelamin lakilaki lebih banyak melakukan cyberloafing yaitu dengan rerata 81,64 dari pada subjek berjenis kelamin perempuan dengan rerata 78,30. Selain itu, subjek laki-laki lebih memiliki IWB dibanding perempuan, dengan perbandingan rerata sebesar $40,23: 35,72$.

Diketahui bahwa selain pendidikan jenjang SMA, semakin tinggi jenjang pendidikan, semakin tinggi pula tingkat cyberloafing dan IWB pada subjek penelitian. Khusus untuk jenjang pendidikan SMA, memiliki nilai rata-rata tingkat cyberloafing yang paling tinggi diantara subjek lainnya, yaitu sebesar 83,88. Namun, pada variabel IWB, memiliki nilai rata-rata yang masih di bawah subjek dengan pendidikan Pascasarjana, dengan perbandingan sebesar 38,13: 42,25.

INSAN Jurnal Psikologi dan Kesehatan Mental

Tahun 2018, Vol. 3(2), 101-113

doi: $10.20473 /$ jpkm.v5i22018.101-113 
Kemudian pada karakteristik jam kerja, pada jam kerja penuh memiliki rata-rata cyberloafing sedikit lebih tinggi daripada subjek yang bekerja paruh waktu atau part-time, dengan selisih perbandingan kecil yaitu 80,06 : 80,13. Meskipun selisih perbandingan dalam cyberloafing kecil, tetapi pada variabel IWB, subjek yang bekerja waktu penuh memiliki tingkat IWB yang jauh lebih tinggi dibandingkan subjek dengan kerja paruh waktu, yaitu dengan perbandingan 35,75 : 38,17.

\section{I S K US I}

Berdasarkan hasil analisis penelitian yang sudah dilakukan, maka dapat disimpulkan bahwa terdapat hubungan yang kuat dengan arah hubungan positif $(r(103)=0,518, p<0,05)$ antara Cyberloafing dengan Innovative Work Behaviour generasi Milenial yang bekerja dalam Industri Kreatif Digital.

Hasil penelitian sebelumnya oleh Derin \& Gökçe (2016) menunjukkan bahwa adanya hubungan positif yang lemah antara cyberloafing dan IWB, hasil ini dikarenakan pada penelitian tersebut justru tidak memberi fokus pada bidang kerja yang membutuhkan kreatifitas dan inovasi. Di sisi lain, tidak semua bidang pekerjaan membutuhkan inovasi dan hanya mengerjakan sesuai peran yang diperintahkan. Berdasarkan keterbatasan tersebut, penulis menggunakan konteks penelitian yang berbeda, yaitu pada generasi milenial yang mana lahir pada saat teknologi digital internet berkembang pesat, sehingga dalam kesehariannya sudah terbiasa menggunakan internet. Selain itu, setting yang digunakan dalam penelitian ini lebih representatif kepada pekerjaan yang memang memerlukan akses teknologi digital internet dalam bekerja.

Hasil yang berbeda juga didapatkan dalam penelitian Palladan (2018) yang menggunakan cyberloafing sebagai variabel mediator hubungan antara IWB dan Job Performance pada bidang kerja pendidik atau dosen, dan menemukan adanya efek moderasi negatif dari aktivitas cyberloafing pada IWB dan kinerja dosen. Cyberloafing justru menurunkan kemampuan inovasi dosen dan kinerja mereka. Hal ini dikarenakan dosen perguruan tinggi di Nigeria menggunakan internet di tempat kerja mereka hanya untuk berbincang-bincang di media sosial dan jarang menggunakannya untuk tujuan akademik (Okechukwu, 2015 dalam Palladan, 2018). Ebele, (2014) (dalam Palladan, 2018) lebih lanjut berpendapat bahwa tingkat e-learning masih pada pasang surut yang lebih rendah di antara lembagalembaga tersier Nigeria lain dan disebabkan oleh buruknya adopsi TIK oleh dosen. Konteks penelitian ini jelas berbeda dengan konteks penelitian penulis sekarang yang merupakan generasi milenial dan dalam setting industri kreatif digital.

Penulis telah melakukan beberapa analisis tambahan untuk mendukung atau menguatkan hasil analisis utama. Pada Analisis Korelasi Parsial, diketahui bahwa dalam variabel cyberloafing, pada dimensi social activity $(r=0,412)$, informational activity $(r=0,483)$, virtual emotional activity $(r=0,322)$, recovery behaviour $(r=0,266)$, development behaviour $(r=0,523)$, dan addiction behaviour $(r=0,398)$ memiliki korelasi dengan IWB dengan beragam besarnya korelasi. Sedangkan pada dimensi leisure activity dan deviant behaviour tidak memiliki korelasi terhadap IWB.

Lim (2002) berpendapat bahwa cyberloafing adalah perilaku tempat kerja yang kontraproduktif yang mengakibatkan deviant behaviour yang mengarah pada deviance production yang mengacu pada tindakan sukarela yang dilakukan oleh karyawan yang melanggar norma organisasi tentang bagaimana pekerjaan harus diselesaikan. Beberapa karyawan tidak dapat menyelesaikan tugas mereka karena cyberloafing dan itu mengurangi produktivitas kerja mereka dan bertentangan dengan etnik kerja yang membahayakan bagi organisasi (Lim \& Chen, 2012; Olajide, dkk., 2018). Tidak masalah jika melakukan rekreasi online atau cyberloafing dalam jumlah yang wajar, karena cyberloafing dapat secara positif terkait dengan kesejahteraan emosional karyawan, tetapi ketika sangat sering dilakukan maka terjadi 
deviance production yang membuat karyawan tidak dapat menyelesaikan tugas mereka (Lim \& Chen, 2012).

Coker (2011) menemukan bahwa workplace Internet leisure browsing (WILB) memiliki dampak sebesar 9\% lebih baik terhadap pekerjaan, tetapi pekerjaan menjadi terpengaruh negatif ketika penggunaan internet rata-rata $12 \%$ atau lebih dari total jam kerja karyawan. WILB dapat memiliki dampak negatif pada kinerja tugas jika mengganggu konsentrasi individu atau keadaan ketika mengerjakan tugas yang membutuhkan sejumlah besar sumber daya kognitif, kerena dapat menantang atau bertentangan secara kognitif, membutuhkan usaha perpindahan fokus untuk 'kembali ke alur' konsentrasi kerja.

Dimensi social activity mengarah pada pemenuhan hubungan sosial menggunakan perangkat dan internet. Dimensi ini memiliki korelasi yang sedang karena sesuai dengan pendapat Yang \& Chen (2005 dalam Li \& Zheng, 2014) yang menyatakan bahwa interaksi dapat meningkatkan resesi emosional dan kepercayaan antara anggota yang tidak hanya kondusif bagi karyawan untuk berbagi pengalaman belajar dan pengetahuan teknologi, tetapi juga memperluas bidang visi, mempromosikan ide-ide baru, dan menghasilkan ide-ide baru. Selain itu, hubungan interpersonal atau sosial yang baik akan menyebabkan perasaan karyawan lebih aman untuk menyuarakan dan berbagi ide-ide secara terbuka (Zhou \& Velamuri, 2018).

Penjelasan dimensi social activity ini berhubungan dengan dimensi cyberloafing informational activity yang juga berkorelasi dengan IWB. Doorn (2011) menyatakan bahwa cyberloafing bisa sangat terkait dengan IWB karena elf-development and searching bisa ditemukan dalam cyberloafing.

Kemudian pada dimensi development behaviour sesuai dengan hasil penelitian Belanger dan Van Slyke (2002, dalam Doorn, 2011) yang menunjukkan bahwa cyberloafing dapat mengarah pada peningkatan pemahaman tentang pengetahuan yang ada atau lebih meningkatkan keakuratan pengetahuan. Selain itu, kegiatan Cyberloafing dapat berfungsi untuk membuka saluran kreatif yang diblokir (Doorn, 2011). Hal ini mengartikan bahwa adanya peningkatan kreativitas karena kegiatan cyberloafing. Zhang, Mayer, \& Hwang (2017) menyatakan bahwa meluangkan waktu untuk mempelajari hal-hal baru di tempat kerja dapat berfungsi sebagai kondisi perlindungan untuk deviant dalam lingkungan kerja yang penuh tekanan, sedangkan meluangkan waktu untuk relaksasi di tempat kerja tampaknya tidak memainkan peran perlindungan yang signifikan dari deviant. Dengan demikian, ketika karyawan dihadapkan pada masa-masa tekanan stres, melakukan lebih banyak untuk mempelajari sesuatu daripada bersantai sebenarnya lebih bermanfaat karena memiliki lebih sedikit deviant di tempat kerja.

Pada dimensi virtual emotional activity dan recovery behaviour berkorelasi dengan IWB dikarenakan ketika tuntutan pekerjaan lebih tinggi dari sumber daya pekerjaan, pemulihan diperlukan untuk mencegah kelelahan (Doorn, 2011). Cyberloafing dapat berperan dalam proses ini dan dapat memiliki efek positif pada kesejahteraan karyawan (Doorn, 2011). Menurut penelitian yang dilakukan oleh Stanton 2002, Oravec 2004, Anandarajan dan Simmers (2005) (dalam Lim \& Chen, 2012) cyberloafing dapat berfungsi sebagai strategi koping paliatif terhadap pengalaman negatif di tempat kerja, seperti stres. Janssen (2000) menemukan bahwa IWB berfungsi sebagai strategi koping yang berfokus pada masalah yang digunakan oleh karyawan untuk mengatasi tingkat tuntutan pekerjaan (job demands) yang lebih tinggi, yang diatur oleh perceptions of effort-reward fairness.

Pada dimensi addiction behaviour juga memiliki korelasi dengan IWB, hasil ini dapat dipahami karena pada zaman dengan perkembangan internet yang pesat, hampir mustahil untuk bekerja tanpa adanya koneksi internet (Derin \& Gökçe, 2016). Chatzoglou \& Vraimaki (2010) menyatakan bahwa penggunaan internet dianggap sebagai perilaku inovatif itu sendiri. Selain itu, pada dimensi addiction behaviour ini diungkapkan intensitas individu untuk mengunjungi situs internet yang sering dikunjungi, hal ini mampu menambah ide dari individu itu sendiri.

INSAN Jurnal Psikologi dan Kesehatan Mental

Tahun 2018, Vol. 3(2), 101-113

doi: 10.20473/jpkm.v5i22018.101-113 
Pada analisis tambahan untuk demografis, penulis menggunakan one-way ANOVA, dengan didapatkan hasil bahwa berdasarkan jenis kelaminnya, laki-laki memiliki tingkat cyberloafing dan IWB yang lebih tinggi daripada perempuan. Hasil ini dikarenakan laki-laki didapati lebih percaya diri dalam penggunaan internet dan cenderung lebih menggunakan internet untuk tujuan hiburan dan rekreasi, sementara perempuan lebih kecil kemungkinannya untuk menggunakan internet karena mereka kurang yakin tentang menavigasi web dan lebih cenderung memiliki sikap negatif terhadap penggunaan internet (Lim \& Chen, 2012). Secara umum, temuan Lim \& Chen (2012) menunjukkan bahwa laki-laki lebih sering dengan durasi yang lebih lama untuk cyberloafing daripada perempuan. Laki-laki juga lebih mungkin untuk online setidaknya beberapa kali sehari dibandingkan dengan perempuan (Lim \& Chen, 2012). Selain itu, subjek laki-laki lebih memiliki IWB dibanding perempuan, dengan perbandingan mean sebesar 40,23:35,72.

Laki-laki lebih menikmati kegiatan cyberloafing karena mereka lebih efisien dalam pencarian internet mereka. Cyberloafers laki-laki lebih mungkin mengalami perolehan sumber daya karena mereka dapat melakukan cyberloaf dengan lebih mudah, mendapatkan lebih banyak kesenangan, dan lebih mampu menerapkan informasi yang terlihat tidak terkait secara langsung dengan pekerjaan, yang sebenarnya mereka menyurvei internet ke tujuan pekerjaan tertentu (Lim \& Chen, 2012). Hal ini berguna untuk memperoleh ide-ide yang mana dapat mengembangkan IWB.

Di sisi lain, perempuan diketahui kurang percaya diri dalam menggunakan internet, dan mengalami lebih banyak informasi yang melimpah dibandingkan dengan pria. Wanita kebih menganggap cyberloafing membuang waktu, informasi yang berlebihan, dan hilangnya sumber daya perhatian terhadap pekerjaan. Konsekuensinya, ini mengarahkan mereka pada pengertian bahwa cyberloafing berdampak negatif pada pekerjaan (Lim \& Chen, 2012).

Berdasarkan jam kerjanya, orang yang bekerja full-time lebih memiliki tingkat IWB yang cukup tinggi dibanding pekerja part-time. Pada Cyberloafinng diketahui terdapat selisih yang relatif kecil antar keduanya, dengan pekerja full-time yang sedikit lebih tinggi daripada pekerja part-time. Hal ini dikarenakan ketika tingkat keterlibatan kerja dan motivasi intrinsik rendah, maka berhubungan dengan tingkat perilaku cyberloafing yang lebih tinggi (Liberman dkk., 2011). Kesimpulan ini menunjukkan bahwa cyberloafing berperan dalam mengatasi kurang adanya motivasi instrinsik karena adanya kesenggangan dalam keterlibatan kerja. Liberman, dkk. (2011) menemukan bahwa karyawan yang memiliki tingkat keterlibatan kerja dan keterlibatan intrinsik yang lebih rendah lebih cenderung terlibat dalam perilaku cyberloafing.

Meskipun selisih perbandingan dalam cyberloafing kecil, tetapi pada variabel IWB, subjek yang bekerja waktu penuh memiliki tingkat IWB yang jauh lebih tinggi dibandingkan subjek dengan kerja paruh waktu, yaitu dengan perbandingan $35,75: 38,17$. Hal ini terkait dengan adanya pembiasaan kerja dan adanya waktu untuk belajar dan mendapatkan pengalaman lebih banyak. Ericsson dkk. (1993) (dalam Li \& Zheng, 2014) menemukan bahwa ketika karyawan merasa terbiasa dengan tugas-tugas dan alur kerja, maka akan mudah menemukan kiat bekerja, mengatasi ketakutan akan kegagalan inovasi, dan lebih percaya diri ketika berinovasi. Karyawan juga harus belajar dan memecahkan setiap masalah baru yang timbul secara terus-menerus, ketika sudah terbiasa, akan merrasakan inovasi yang mendalam dan keterampilan inovatif tingkat tinggi. Sementara itu, ketika bekerja part-time, variasi tantangan tidak seperti bekerja full-time. Part-time hanya menjalankan rutinitas pengulangan sistem atau aturan dalam bekerja yang tinggi, yang justru akan membentuk pemikiran yang solid, dan berdampak pada niat dan perilaku inovatif yang rendah (Li \& Zheng, 2014).

Pada karakteristik kelompok berdasarkan pendidikan terakhir, subjek dengan jenjang pendidikan SMA memiliki nilai rata-rata tingkat cyberloafing yang paling tinggi diantara subjek lainnya, yaitu sebesar 83,88 . Namun, pada variabel IWB nilai rata-rata IWB tertinggi adalah pada pendidikan Pascasarjana, INSAN Jurnal Psikologi dan Kesehatan Mental Tahun 2018, Vol. 3(2), 101-113 doi: $10.20473 /$ jpkm.v5i22018.101-113 
yaitu sebesar 42,25. Rentang rata-rata subjek dengan masing-masing tingkat pendidikan yang dimiliki memiliki jarak yang kecil.Pada variabel IWB subjek dengan pendidikan Pascasarjana memiliki tingkat rata-rata IWB yang paling tinggi, yaitu sebesar 42,25. Hal ini dikarenakan adanya faktor fungsional, yang terdiri dari bakat, kemampuan, sikap, nilai, motif, dan kebutuhan, nilai-nilai tersebut berkolerasi positif dengan IWB (Li \& Zheng, 2014). Selain itu, diketahui bahwa rentang rata-rata subjek dengan masingmasing tingkat pendidikan yang dimiliki, memiliki selisih perbandingan yang kecil, hal ini dikarenakan subjek merupakan generasi milenial yang memiliki karakteristik percaya diri, keyakinan ini berasal dari kepercayaan dan optimisme mereka (Kowske dkk., 2010). Milenial juga fokus pada pencapaian. Mereka memiliki kebutuhan tidak hanya untuk melakukannya dengan baik, tetapi untuk unggul dan melampaui semua tujuan dan aspirasi (Kaifi dkk., 2012). Ini mengarahkan mereka untuk mencari peluang belajar baru.

\section{S I M P U L A N}

Berdasarkan hasil analisis penelitian ini, diketahui bahwa terdapat hubungan yang kuat dengan arah hubungan positif $(r(103)=0,518, p<0,05)$ antara Cyberloafing dengan Innovative Work Behaviour generasi Milenial yang bekerja dalam Industri Kreatif Digital. Pada dimensi social activity, informational activity, virtual emotional activity, recovery behaviour, development behaviour, dan addiction behaviour memiliki korelasi dengan IWB dengan beragam tingkat korelasinya. Sedangkan pada dimensi leisure activity dan deviant behaviour tidak memiliki korelasi terhadap IWB.

Penelitian selanjutnya diharapkan bisa menggunakan survei secara offline untuk mengetahui kondisi subjek secara langsung. Peneliti juga bisa menggunakan metode survei yang menilai orang lain (atasan, bawahan, pelanggan, atau rekan kerja) untuk untuk mengkonfirmasi jawaban responden dan meminimalisir kemungkinan terjadinya bias respon kuesioner, yaitu adanya choice-supportive bias yang berarti bahwa responden menjawab berdasarkan pada hal yang diyakini benar dan positif. Dikarenakan adanya hasil korelasi atau hubungan yang kuat dengan arah hubungan positif $(r=0,518>0,05)$ antara cyberloafing dengan innovative work behaviour generasi milenial yang bekerja dalam Industri Kreatif Digital, penelitian selanjutnya bisa memfokuskan untuk menggungkap pengaruh antar variabel Cyberloafing dengan IWB.

Beberapa dimensi atau aspek dari cyberloafing memiliki hubungan yang positif terhadap IWB, sehingga manajerial harus mempertimbangkan cyberloafing sebagai cara istirahat bagi karyawan generasi milenial untuk berpikir inovatif. Yang perlu diperhatikan justru mencari metode kerja sehari-hari dengan memanfaatkan perkembangan teknologi internet untuk bisa berkompetisi dengan inovasi. Misalnya mengenalkan situs internet dan/ atau membuat platform untuk melakukan komunikasi maupun diskusi terkait dengan pekerjaan dalam perusahaan tersebut. Selain itu, managerial bisa melakukan training terkait pemanfaatan teknologi internet digital, agar pekerja generasi milenial lebih bisa memahami pemanfaatannya untuk kepentingan inovasi dalam bekerja beserta dampak lainnya.

\section{U CAPAN TERIMA KASIH}

Penulis berterima kasih kepada Tuhan dan seluruh pihak yang mendukung atau membantu dalam proses pembuatan penelitian ini, baik secara langsung maupun tidak langsung. Sehingga penelitian ini dapat terselesaikan dengan baik. 


\section{DEKLARASI POTENSI TERJADINYA KONFLIK KEPENTINGAN}

Kurnia Sri Wijanarko dan Herison Pandapotan Purba tidak bekerja, menjadi konsultan, memiliki saham, atau menerima dana dari perusahaan atau organisasi mana pun yang akan mengambil untung dari naskah ini, dan telah mengungkapkan bahwa ia tidak memiliki afiliasi selain yang telah disebut di atas.

\section{PUSTAKA ACUAN}

Allen, T. D., Jenny, G. J., Bauer, G. F., Brauchli, R., \& Wepfer, A. G. (2017). Work-Life Boundaries and WellBeing: Does Work-to-Life Integration Impair Well-Being through Lack of Recovery? Journal of Business and Psychology, 33(6), 727-740. https://doi.org/10.1007/s10869-017-9520-y

Aslam, H., Aslam, B., \& Ismail, L. (2017). The Effect of Employee's Innovative Work Behaviour on Innovative Output. Global Journal of Research in Business \& Management, 6(2), 461-468.

Bukht, R., \& Heeks, R. (2017). Defining, Conceptualising and Measuring the Digital Economy. Manchester: Centre for Development Informatics.

Chatzoglou, P. D., \& Vraimaki, E. (2010). Investigating Internet Usage as Innovation Adoption: A Quantitative Study. Journal of Information, Communication and Ethics in Society, 8(4), 338-363. https://doi.org/10.1108/14779961011093345

Coker, B. L. S. (2011). Freedom to Surf: The Positive Effects of Workplace Internet Leisure Browsing. New Technology, Work and Employment, 26(3), 238-247. https://doi.org/10.1111/j.1468005X.2011.00272.X

Cornell University, INSEAD, \& World Intellectual Property Organization. (2018). Global innovation index 2018: Energizing the World with Innovation. (S. Dutta, B. Lanvin, \& S. Wunsch-Vincent, Eds.) (11th Editi). Ithaca, Fontainebleau, dan Geneva.

Dahlman, C., Mealy, S., \& Wermelinger, M. (2016). Harnessing The Digital Economy for Developing Countries. Paris: OECD Development Centre. https://doi.org/10.1787/4adffb24-en

Daniel, R., Fleischmann, K., \& Welters, R. (2017). Professional Development in the Creative Industries: Methods and Insights from Regional Practitioners. Australian Journal of Career Development, 26(3), 113-123. https://doi.org/10.1177/1038416217720780

De Jong, J., \& Den Hartog, D. (2010). Measuring innovative work behavior. Creativity and Innovation Management, 19(1), 23-36. https://doi.org/https://doi.org/10.1111/j.1467-8691.2010.00547.x

Derin, N., \& Gökçe, S. G. (2016). Are Cyberloafers Also Innovators?: A Study on the Relationship between Cyberloafing and Innovative Work Behavior. Procedia - Social and Behavioral Sciences, 235(October), 694-700. https://doi.org/10.1016/j.sbspro.2016.11.070

Dinperindag Provinsi Jawa Tengah. (2014). Industri Kreatif. Semarang: Dinperindag Provinsi Jawa Tengah.

Doorn, O. N. Van. (2011). Cyberloafing: A Multi-dimensional Construct Placed in A Theoretical Framework. Eindhoven University of Technology The Netherlands.

Handke, C., \& Towse, R. (2016). Handbook on the Digital Creative Economy. (C. Handke \& R. Towse, Eds.), Journal of Business \& Finance Librarianship (Vol. 21). Cheltenham: Edward Elgar Publishing. https://doi.org/10.1080/08963568.2016.1169149

INSAN Jurnal Psikologi dan Kesehatan Mental

Tahun 2018, Vol. 3(2), 101-113

doi: 10.20473/jpkm.v5i22018.101-113

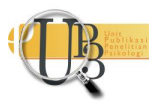


Indah Budiati, Susianto, Y., Adi P, W. P., Ayuni, S., Reagan, H. A., Larasaty, P., ... Saputri, V. G. (2018). Statistik Gender Tematik: Profil Generasi Milenial Indonesia. (A. Said, I. Budiati, T. R. B. Rahayu, \& A. P. Raharjo, Eds.). Kementerian Pemberdayaan Perempuan dan Perlindungan Anak.

Internet World Stats. (2017). Internet Growth Statistics 1995 to 2017 - the Global Village Online.

Janssen, O. (2000). Job Demands, Perceptions of Effort-reward Fairness and Innovative Work Behaviour. Journal of Occupational and Organizational Psychology, 73, 287-302. https://doi.org/10.1016/j.aquaculture.2010.01.018

Kaifi, B. A., Nafei, A. W., Khanfar, N. M., \& Kaifi, M. M. (2012). A Multi-Generational Workforce : Managing and Understanding Millennials. International Journal of Business and Management, 7(24). https://doi.org/10.5539/ijbm.v7n24p88

Kim, S. (2018). Managing Millennials' Personal Use of Technology at Work. Business Horizons, 61(2), 261-270. https://doi.org/10.1016/j.bushor.2017.11.007

Koay, K., \& Soh, P. C. (2018). Should Cyberloafing be Allowed in the Workplace? Human Resource Management International Digest, 26(7). https://doi.org/10.1108/HRMID-05-2018-0107

Kowske, B. J., Rasch, R., \& Wiley, J. (2010). Millennials' (Lack of) Attitude Problem: An Empirical Examination of Generational Effects on Work Attitudes. Journal of Business and Psychology, 25(2), 265-279. https://doi.org/10.1007/s10869-010-9171-8

Levickaite, R. (2011). Four Approaches To the Creative Economy: General Overview. Business, Management and Education, 9(1), 81-92. https://doi.org/10.3846/bme.2011.06

Li, X., \& Zheng, Y. (2014). The Influential Factors of Employees' Innovative Behavior and the Management Advices. Journal of Service Science and Management, 7, 446-450. https://doi.org/10.4236/jssm.2014.76042

Liberman, B., Seidman, G., McKenna, K. Y. A., \& Buffardi, L. E. (2011). Employee Job Attitudes and Organizational Characteristics As Predictors of Cyberloafing. Computers in Human Behavior, 27(6), 2192-2199. https://doi.org/10.1016/j.chb.2011.06.015

Lim, V. K. G. (2002). The IT Way of Loafing on The Job : Cyherloafing, Neutralizing and Organizational Justice. Journal of Organizational Behavior, 23(1), 675-694. https://doi.org/10.1002/job.l61

Lim, V. K. G., \& Chen, D. J. Q. (2012). Cyberloafing at The Workplace: Gain or Drain on Work? Behaviour and Information Technology, 31(4), 343-353. https://doi.org/10.1080/01449290903353054

Lim, V. K. G., \& Teo, T. S. H. (2005). Prevalence, Perceived Seriousness, Justification and Regulation of Cyberloafing in Singapore: An Exploratory Study. Information and Management, 42(8), 1081-1093. https://doi.org/10.1016/j.im.2004.12.002

Olajide, O., Abdu, M., \& Abdul-Qadir, A. B. (2018). Effect of Cyberloafing on Employee Performance among Deposit Money Banks in Kaduna Metropolis. Online Journal of Arts, Management and Social Sciences (OJAMSS), 3(1), 27-37.

Palladan, A. A. (2018). Moderating Effects of Cyberloafing Activity on Innovative Work Behaviour and Lecturers Job Performance. International Journal of Advanced Studies in Social Science \& Innovation, 2(1), 28-49. https://doi.org/10.30690/ijassi.21.03

Pallant, J. (2016). SPSS Survival Manual: A Step by Step Guide to Data Analysis Using IBM SPSS (6th Editio).

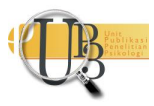


New York: Open University Press.

Ross, J. (2018). ' Cyberloafing ' in Health Care : A Real Risk to Patient Safety. Journal of PeriAnesthesia Nursing, 33(4), 560-562. https://doi.org/10.1016/j.jopan.2018.05.003

Spector, P. E., Goh, A., Bruursema, K., Kessler, S., Penney, L. M., \& Fox, S. (2005). The Dimensionality of Counterproductivity: Are All Counterproductive Behaviors Created Equal? Journal of Vocational Behavior, 68(3), 446-460. https://doi.org/10.1016/j.jvb.2005.10.005

Theurer, C. P., Tumasjan, A., \& Welpe, I. M. (2018). Contextual Work Design and Employee Innovative Work Behavior: When Does Autonomy Matter? Plos One, 13(10), 1-35. https://doi.org/10.1371/journal.pone.0204089

Yogun, A. E. (2015). Cyberloafing and Innovative Work Behavior Among Banking Sector Employee. International Journal of Business and Management Review, 3(10), 61-71.

Zhang, C., Mayer, D. M., \& Hwang, E. (2017). More is less: Learning but not relaxing buffers deviance under job stressors. Journal of Applied Psychology, 103(2), 123-136. https://doi.org/10.1037/apl0000264

Zhou, W., \& Velamuri, V. K. (2018). Key Contextual Success Factors for Employee Innovative Behavior: A Study in A Foreign Manufacturing Subsidiary in China. Cogent Business \& Management, 5, 1-18. https://doi.org/10.1080/23311975.2018.1471770 